\title{
PREVALENCE, IDENTIFICATION AND DISTRIBUTION OF VARIOUS ENTEROCOCCAL SPECIES ISOLATED IN KATIHAR DISTRICT, BIHAR WITH SPECIAL REFERENCE TO VRE.
}

Priyanka Paul Biswas, Sangeeta Dey, Luna Adhikary, Aninda Sen, Udayan Ganguly, Umesh

1. Assistant Professor. Department of Microbiology, Katihar Medical College, Katihar.

2. Professor \& HOD. Department of Microbiology, Katihar Medical College, Katihar.

3. Professor. Department of Microbiology, Sikkim Manipal University, Gangtok.

4. Professor. Department of Microbiology, Katihar Medical College, Katihar.

5. Professor. Department of Microbiology, Katihar Medical College, Katihar.

6. Associate Professor. Department of Microbiology, Government Medical College, Haldwani.

\section{CORRESPONDING AUTHOR}

Mrs. Priyanka Paul Biswas,

Assistant Professor,

Department of Microbiology,

Katihar Medical College,

Karim Bagh, Katihar. Bihar 854105

E-mail: priyankaonli@yahoo.in

Ph: 00918544036075

ABSTRACT: BACKGROUND: Identification of enterococci to species level in order to determine the species prevalent in this geographic region and also to determine the species-specific antimicrobial susceptibility pattern. OBJECTIVE: To detect and determine glycopeptide resistance by screening for vancomycin resistant enterococci (VRE) in both colonized and infected patients. METHODS: A total of 123 isolates of enterococcus species were recovered from various clinical and faecal samples of hospitalized patients, from September 2010 to June 2011. Various species of enterococci were identified by standard methods. Vancomycin susceptibility in enterococci was detected by disc diffusion method (DDM), vancomycin screen agar method (VSAM) and agar dilution method to determine minimum inhibitory concentration (MIC). RESULTS: E. faecalis was the predominant isolate from the clinical and faecal samples. Multidrug resistance was more in E. faecium than E. faecalis. MIC method could detect 7 VRE and 27 strains with reduced susceptibility to vancomycin. Disk diffusion test and vancomycin screen agar failed to detect $50 \%$ and $29.4 \%$ of resistant strains respectively. CONCLUSION: Vancomycin resistance was also detected in less virulent strains of enterococcus like E. gallinarum and E. dispar. In laboratories where performance of MIC studies is not feasible, VSAM method should be preferred over the DDM for detection of vancomycin resistance in enterococci.

KEY WORDS: Enterococcus species, vancomycin resistant enterococci (VRE), multi drug resistant enterococci (MDRE)

INTRODUCTION: Although considered benign and opportunistic pathogens, Enterococci have long been known to cause endocarditis in hospitalized patients. Their resistance to several antimicrobial agents, whether intrinsic (low level resistance to penicillin, cephalosporins and aminoglycosides) or acquired ((high level aminoglycoside resistance) is of great concern. ${ }^{(1)}$ This increasing prevalence has been paralleled by the occurrence of vancomycin-resistant strains, which were first reported in 1988. (2) Recently VRE and MDRE have emerged as a leading cause 
of nosocomial infections in patients who are either debilitated or as superadded infection especially in surgical and tertiary care units, particularly after organ transplants. These strains are emerging as causes of meningitis and other infections of the central nervous system in neonates and as osteomyelitis, lung infection, urinary tract and pelvic infections in adults. (1)

Antibiotics that achieve high gastrointestinal concentration but are inactive against enterococci favour colonization of the gastro intestinal tract with VRE. Colonization with VRE can lead to serious diseases like urinary tract infections, bacteremia and VRE sepsis which can be fatal. (3)

To the best of our knowledge no study on enterococcus has been carried out in Bihar and Eastern parts of India regarding its characterization to species level and the burden of VRE in this region. The main objectives of the present study were to identify the species of enterococcus isolated from both clinical and faecal samples, which indicated colonization, determine their antimicrobial susceptibility pattern and look for the presence of VRE in the strains isolated.

\section{MATERIAL AND METHODS:}

STUDY POPULATION: A total of 123 isolates of enterococcus species were recovered from various clinical and stool samples of hospitalized patients, from September 2010 to June 2011. 60 strains of enterococcus species were isolated from various samples like urine, catheter tip, pus, drainage fluid, tracheal aspirate and blood. An additional 63 strains of enterococcus were also isolated from fecal samples of hospitalized patients who were otherwise not suffering from any other infection, to look for colonization with enterococcus species. The criteria for VRE infection or colonization were: hospitalization for 5 days or more, use of antimicrobials (cephalosporins, aminoglycosides and fluroquinolones).

ISOLATION \& IDENTIFICATION: Enterococci were identified using standard methods based on Gram staining, catalase reaction, hydrolysis of bile esculin, growth in $6.5 \% \mathrm{NaCl}$, growth at $10^{\circ} \mathrm{C}$ and $40^{\circ} \mathrm{C}$, growth at $\mathrm{pH} 9.6$, heat test, hydrolysis of leucine-beta-napthalamide (LAP) and L-pyrrolidonyl- $\beta$-napthalamide (PYR). Further identification to species level were based on carbohydrate fermentation using $1 \%$ solution of following sugars: glucose, lactose, mannitol, sucrose, arabinose, sorbose, sorbitol, raffinose, ribose, trehalose, xylose, melibiose, glycerol; by pigment production, motility test, pyruvate utilization in $1 \%$ pyruvate broth, acidification of methyl-alpha-D-glucopyranoside, Voges-Proskeuer test, arginine decarboxylation, hippurate hydrolysis, reduction of potassium tellurite and tetrazolium chloride. $(4,5,6)$

ANTIMICROBIAL SUSCEPTIBILITY TESTING: Antibiotic susceptibility test was done by Kirby Bauer disc diffusion method on Muller Hinton agar. Inoculum was prepared and adjusted to 0.5 Mc Farland's turbidity standard. Antibiotic disc were obtained from the Hi Media Laboratories (Mumbai) viz ampicillin (10 $\mu \mathrm{gm})$, ampicillin/sulbactam $(10 / 10 \mu \mathrm{gm})$, penicillin (10 units), piperacillin $(100 \mu \mathrm{gm})$, tetracycline $(30 \mu \mathrm{gm})$, ciprofloxacin $(5 \mu \mathrm{gm})$, erythromycin $(15 \mu \mathrm{gm})$, vancomycin $(30 \mu \mathrm{gm})$, teicoplanin $(30 \mu \mathrm{gm})$, linezolid $(30 \mu \mathrm{gm}) \&$ imipenem (30 $\mu \mathrm{gm})$. The test was quality controlled using E. faecalis ATCC 51299 and E. faecalis ATCC 29212. (7)

Detection of vancomycin resistance in enterococci by vancomycin screen agar method: 
For the agar screen method brain heart infusion agar (Hi Media, Mumbai) was supplemented with $6 \mu \mathrm{gm} / \mathrm{ml}$ of vancomycin. The test organisms were grown in peptone water and the turbidity was matched with 0.5 Mc Farland's standard. The bacterial strains were spot inoculated on the agar medium using $10 \mu \mathrm{l}$ of bacterial culture. The plates were incubated at $37^{\circ} \mathrm{C}$ for 24 hours. Presence of more than one colony or a haze of growth after 24-hour incubation was read as resistance. $(7,8)$

Determination of MIC by agar dilution method: Agar dilution was used to determine MIC of vancomycin to enterococci. Brain-heart infusion agar (Hi Media, Mumbai) was supplemented with different concentrations of vancomycin. The test organism was grown in broth and the turbidity matched with Mc Farland's 0.5 standard. The bacterial strains were spot inoculated on the surface of agar medium using $10 \mu \mathrm{l}$ of bacterial culture. The plates were incubated at $37^{\circ} \mathrm{C}$ for 24 hours. The minimum concentration of vancomycin, which inhibited bacterial growth, was considered MIC. Enterococci which had MIC $\geq 32 \mu \mathrm{gm} / \mathrm{ml}$ were considered resistant; MIC of 8-16 $\mu \mathrm{gm} / \mathrm{ml}$ as intermediately resistant; and MIC of $\leq 4 \mu \mathrm{gm} / \mathrm{ml}$ as susceptible to vancomycin. ${ }^{(8)}$

RESULTS: Out of the 60 enterococcal strains isolated from clinical samples, 27(46\%) were identified as E. faecalis, $26(43 \%)$ as E. faecium, $3(5 \%)$ as E. solitarius and $2(3.3 \%)$ each as E. raffinosus and E. gallinarum. The majority of the isolates from the fecal samples were E. faecalis $28(44.4 \%)$ followed by E. gallinarum $22(34.9 \%)$, E. faecium $11(17.7 \%)$ and $1(1.5 \%)$ each of E. raffinosus and E. dispar.

Enterococcal strains, both clinical isolates and isolates from faeces of colonized patients showed resistance to various antibiotics. Antibiotics to which maximum resistance was seen were piperacillin, ciprofloxacin, penicillin, ampicillin and imipenem. Clinical isolates showed least resistance to vancomycin, teicoplanin and linezolid whereas faecal isolates showed least resistance to linezolid, teicoplanin and vancomycin. However vancomycin resistance was seen in $14.2 \%$ of faecal isolates as compared to $1.6 \%$ of clinical isolates.(Table 1) Amongst the faecal isolates, $27.2 \%$ of E. faecium were found to be VRE and $10.7 \%$ of E. faecalis. Multidrug resistance amongst clinical isolates was more in E. faecium; $73 \%$ of these strains showing complete resistance to imipenem.(Table 1) Out of the total of 123 clinical and faecal isolates, 17 and 24 isolates were resistant to vancomycin by disc diffusion method(DDM) \& vancomycin agar screen method(VASM).(Table2) The highest resistance was observed among E.faecalis followed by E. faecium and E. gallinarum by agar screen method.

MIC test of various clinical strains of enterococcus to vancomycin showed 8 strains to have reduced susceptibility to vancomycin i.e. MIC ranging from 8 to $16 \mu \mathrm{gm} / \mathrm{ml}$. Only one strain of E. faecium had MIC $\geq 32 \mu \mathrm{gm} / \mathrm{ml}$ and was considered as VRE. (Table 3)Faecal isolates on the other hand were found to be more resistant to vancomycin with 19 strains showing reduced susceptibility and six showing resistance i.e. MIC $\geq 32 \mu \mathrm{gm} / \mathrm{ml}$.(Table 4)

Amongst the 9 clinical VRE and or VIE, 4 (44.4\%) strains were isolated from urinary tract infections (UTI), 3 (33.3\%) from wound infection and 2 (22.2\%) from blood stream infection (BSI). On the other hand 25 faecal isolates were found to be VRE/VIE. The predominant clinical presentations in the VRE positive cases were appendicitis, hernia, burn, granuloma, swelling of body and hepatosplenomegaly.

DISCUSSION: Combination of colonizing abilities and drug resistance both inherent and acquired, has made Enterococci attain greater significance as human pathogens. In the present 
study, E. faecalis was the predominant species isolated from both clinical \& fecal specimens. Other studies done on Enterococci also support the same finding. This is probably due to predominance of E. faecalis in the endogenous flora of human body. $(9,10)$

The major sources of VRE are from the clinical environment. (11,12) In our study, VRE strains were isolated from faecal samples of colonized patients. The VRE species isolated from these samples were E. faecium followed by E. faecalis, E. gallinarum and E. dispar. Patients infected or colonized with VRE did not show any clear correlation between the use of antimicrobials or gastrointestinal tract surgery.

The incidence of infection with strains of enterococcus with glycopeptides resistance has increased dramatically. In the present study DDM and VASM test failed to detect $50 \%$ and $29.4 \%$ strains respectively. The DDM failed to recognize as resistant those strains that have reduced susceptibility to vancomycin. The MIC test not only detected 7 VRE but also another 27 enterococcal strains with reduced susceptibility to vancomycin. The MIC test may therefore be considered as the gold standard. This observation is consistent with that made in a previous report. (8)The treatment of vancomycin resistant enterococci is a major problem. Vancomycin resistance eliminates the synergistic activity usually achieved by aminoglycoside combination, thus leaving beta-lactams as the only choice to combine with aminoglycoside. Moreover many of the vancomycin resistant enterococci are multidrug resistant. The antibiotic of choice for such multidrug resistant enterococci is currently not known. (8)

Out of the 63 stool isolates, 9 strains were resistant to 9 antibiotics out of the 10 antibiotics used. The outcome of infections with such multidrug resistant Enterococcus strains might be fatal. In most of the earlier reports, such high MDR rates were rarely observed in enterococci. High resistance of the clinical strains of E. faecalis to penicillin could be due to low affinity of penicillin binding proteins or production of beta lactamases. (9)

We conclude that enterococcal strains with high rate of resistance to multiple drugs are not only prevalent in the clinical environment but also in the gastrointestinal tract of the colonized patients. However patients with VRE infections and those showing resistance to multiple drugs could not be followed up, so the actual outcome of the infections with these strains could not be found out.

The prevalence of VRE was quite high amongst the colonized patients. This situation makes it mandatory for the clinical microbiologists to try to identify the most useful active antibiotic for treatment. The time has come for proper control measures to be taken to prevent the spread of such infections. MIC for vancomycin should be performed, in laboratories equipped to perform these tests to keep record of increasing resistance of enterococci to vancomycin.

\section{REFERENCES:}

1. Singh BR. Prevalence of vancomycin resistance and multiple drug resistance in enterococci in equids in North India. J Infect Dev Ctries 2009; 7:498-503.

2. Schouten MA, Hoogkamp-Korstanje JAA, Meis JFG, Voss A. Prevalence of VancomycinResistant Enterococci in Europe. J Clin Microbiol Infect Dis 2000; 19:816-866

3. Javadi A, Ataei B, Khorvash F, Toghyani S, Mobasherzadeh S, Soghrati M. Prevalence of Vancomycin resistant enterococci colonization in gastrointestinal tract of hospitalized patients. Iranian J of Clin Infect Dis 2008;3: 137-141 
4. Desai PJ, Pandit D, Mathur M, Gogate A. Prevalence, identification and distribution of various species of enterococci isolated from clinical specimens with special reference to urinary tract infection in catheterized patients. Indian J Med Microbiol 2001; 3:132-137

5. Facklam R, Collin. Identification of enterococcus species isolated from human infection by a conventional test scheme. J Clin Microbiol1989; 27:731-734

6. Overview of Bacterial Identifications Methods and Strategies. In: Bailey \& Scott?s Diagnostic Microbiology.12th ed. Forbes Betty A, Sahm Daniel L, Weissfeld Allice S, editors. (Mosby Inc, Missouri; 2007: 216-241)

7. Swenson Jana M, Patel Jean B, Jorgensen James H. Special Phenotypic Methods for Detecting Antibacterial Resistance. Vol. 1.9th ed. Murray Patrick R, Baron Ellen Jo, Jorgensen James H, Landry Marie Louise and Pfaller Michael A, editors. (ASM Press, Washington D.C, 2007: 1152-1172.)

8. Adhikary L. High-level aminoglycoside resistance and reduced susceptibility to vancomycin in nosocomial enterococci. J. of Global Infectious Disease 2010; 2:231-234.

9. Gupta V, Sigla N. Speciation and antimicrobial susceptibility pattern of enterococci from a tertiary health care center of North India. J of Clin and Diag Res 2007; 1: 385-389.

10. Marcus N. Rapid increase in the prevalence of antimicrobial drug resistance among enterococcal blood isolates in southern Isreal. Eur J Clin Microbiol Infect Dis 1997; 45: 79-82

11. Woodford N. Glycopeptide - resistant enterococci: a decade of experience. J Med Microbial 1998; 47: 849-862.

12. Ooi WL, Haryiani Y, Lesley M.B., Tunung R., Jurin G., Wong CMVL. Vancomycin Resistant Enterococci (VRE) In Poultry, Vegetables, Enviornmental and Clinical Sources. Malays Appl Biol 2006; 35: 49-56.

Table 1: Resistance pattern of different enterococcus species

\begin{tabular}{|c|c|c|c|c|c|c|c|c|c|c|}
\hline \multirow[t]{2}{*}{ Antibiotics } & \multicolumn{5}{|c|}{$\begin{array}{l}\text { Clinical Isolates }(n=60) \\
\text { No. of resistant strains }\end{array}$} & \multicolumn{5}{|c|}{$\begin{array}{l}\text { Fecal Isolates }(n=63) \\
\text { No. of resistant strains }\end{array}$} \\
\hline & $\begin{array}{l}\text { E.faeca } \\
\text { lis }\end{array}$ & $\begin{array}{l}\text { E.faeci } \\
\text { um }\end{array}$ & $\begin{array}{l}\text { E.solitar } \\
\text { ius }\end{array}$ & $\begin{array}{l}\text { E.raffino } \\
\text { sus }\end{array}$ & $\begin{array}{l}\text { E.gallinar } \\
\text { um }\end{array}$ & $\begin{array}{l}\text { E.faeca } \\
\text { lis }\end{array}$ & $\begin{array}{l}\text { E.faeci } \\
\text { um }\end{array}$ & $\begin{array}{l}\text { E.gallinar } \\
\text { um }\end{array}$ & $\begin{array}{l}\text { E.disp } \\
\text { ar }\end{array}$ & $\begin{array}{l}\text { E.raffino } \\
\text { sus }\end{array}$ \\
\hline Penicillin & $\begin{array}{l}22 \\
(81.4)\end{array}$ & $\begin{array}{l}12 \\
(46.1)\end{array}$ & 0 & 0 & 0 & $\begin{array}{l}20 \\
(71.4)\end{array}$ & $\begin{array}{l}3 \\
(27.2)\end{array}$ & 0 & 0 & 0 \\
\hline Ampicillin & $\begin{array}{l}7 \\
(25.9)\end{array}$ & $\begin{array}{l}12 \\
(46.1)\end{array}$ & 0 & 0 & 0 & $\begin{array}{l}13 \\
(46.4)\end{array}$ & $\begin{array}{l}4 \\
(54.5)\end{array}$ & $9(40.9)$ & $\begin{array}{l}1 \\
(100)\end{array}$ & 0 \\
\hline $\begin{array}{l}\text { Ampicillin/sulba } \\
\text { ctam }\end{array}$ & $\begin{array}{l}10 \\
(37)\end{array}$ & $\begin{array}{l}10 \\
(38.4)\end{array}$ & 0 & 0 & 0 & $\begin{array}{l}16 \\
(57.1)\end{array}$ & $\begin{array}{l}7 \\
(63.6)\end{array}$ & $11(50)$ & $\begin{array}{l}1 \\
(100)\end{array}$ & 0 \\
\hline Tetracycline & $\begin{array}{l}10 \\
(37)\end{array}$ & $\begin{array}{l}10 \\
(38.4)\end{array}$ & $1(33.3)$ & $1(50)$ & $1(50)$ & $\begin{array}{l}20 \\
(71.4)\end{array}$ & $\begin{array}{l}6 \\
(54.5)\end{array}$ & 7 (31.8) & 0 & 0 \\
\hline Piperacillin & $\begin{array}{l}25 \\
(92.5)\end{array}$ & $\begin{array}{l}20 \\
(76.9)\end{array}$ & $1(33.3)$ & $1(50)$ & $1(50)$ & $\begin{array}{l}28 \\
(100)\end{array}$ & $\begin{array}{l}10 \\
(90.9)\end{array}$ & $19(86.3)$ & $\begin{array}{l}1 \\
(100)\end{array}$ & $1(100)$ \\
\hline Ciprofloxacin & $\begin{array}{l}24 \\
(88.8)\end{array}$ & $\begin{array}{l}12 \\
(46.1)\end{array}$ & $2(66.6)$ & $1(50)$ & 0 & $\begin{array}{l}27 \\
(96.4)\end{array}$ & $\begin{array}{l}9 \\
(81.8)\end{array}$ & $15(68.1)$ & 0 & $1(100)$ \\
\hline Linezolid & $2(7.4)$ & $\begin{array}{l}3 \\
(11.5)\end{array}$ & 0 & 0 & 0 & $1(3.5)$ & $\begin{array}{l}2 \\
(18.1)\end{array}$ & $1(4.54)$ & 0 & 0 \\
\hline Imipenem & $\begin{array}{l}10 \\
(37)\end{array}$ & $\begin{array}{l}19 \\
(73)\end{array}$ & 0 & 0 & 0 & $\begin{array}{l}20 \\
(71.4)\end{array}$ & $\begin{array}{l}7 \\
(63.6)\end{array}$ & 19 (86.3) & 0 & 0 \\
\hline Vancomycin & 0 & $\begin{array}{l}1 \\
(3.84)\end{array}$ & 0 & 0 & 0 & $\begin{array}{l}3 \\
(10.7)\end{array}$ & $\begin{array}{l}3 \\
(27.2)\end{array}$ & $2(9.1)$ & $\begin{array}{l}1 \\
(100)\end{array}$ & 0 \\
\hline Teicoplanin & $1(3.7)$ & 0 & 0 & 0 & 0 & $\begin{array}{l}3 \\
(10.7)\end{array}$ & $\begin{array}{l}2 \\
(18.1)\end{array}$ & 0 & 0 & 0 \\
\hline
\end{tabular}

Figures in parenthesis indicate percentages 
Table 2: Distribution of resistant strains of enterococcus species detected by both DDM \& VSAM:

\begin{tabular}{|c|c|c|c|c|c|c|c|c|c|c|}
\hline \multirow{2}{*}{$\begin{array}{l}\text { Methods } \\
\text { used to } \\
\text { detect } \\
\text { vancomycin } \\
\text { resistance }\end{array}$} & \multicolumn{5}{|c|}{$\begin{array}{l}\text { Clinical Isolates }(n=60) \\
\text { No. of resistant strains }\end{array}$} & \multicolumn{5}{|c|}{$\begin{array}{l}\text { Faecal Isolates }(n=63) \\
\text { No. of resistant strains }\end{array}$} \\
\hline & $\begin{array}{c}\text { E.faecalin } \\
\text { (27) }\end{array}$ & $\begin{array}{c}\text { E.faecium } \\
\mathrm{n}(26)\end{array}$ & $\begin{array}{l}\text { E.solitarius } \\
\mathrm{n}(3)\end{array}$ & $\begin{array}{l}\text { E.raffinosus } \\
\mathrm{n}(2)\end{array}$ & $\begin{array}{c}\text { E.gallinarum } \\
\mathrm{n}(2)\end{array}$ & $\begin{array}{l}\text { E.faecalis } \\
\mathrm{n}(28)\end{array}$ & $\begin{array}{c}\text { E.faecium } \\
\text { n (11) }\end{array}$ & $\begin{array}{l}\text { E.gallinarm } \\
\mathrm{n}(22)\end{array}$ & $\begin{array}{c}\text { E.dispar } \\
\mathrm{n}(1)\end{array}$ & $\begin{array}{l}\text { E.raffinosus } \\
\text { n (1) }\end{array}$ \\
\hline $\begin{array}{c}\text { Disc- } \\
\text { diffusion } \\
\text { method } \\
\text { (strains } \\
\text { showing } \\
\text { intermediate- } \\
\text { resistance \& } \\
\text { completee } \\
\text { resistant }\end{array}$ & 2 & 3 & 0 & 0 & 0 & 5 & 4 & 2 & 0 & 1 \\
\hline TOTAL & \multicolumn{5}{|c|}{5} & \multicolumn{5}{|c|}{12} \\
\hline $\begin{array}{l}\text { Vancomycin } \\
\text { gar screen } \\
\text { method }\end{array}$ & 3 & 4 & 0 & 0 & 0 & 7 & 5 & 4 & 0 & 1 \\
\hline TOTAL & \multicolumn{5}{|c|}{7} & \multicolumn{5}{|c|}{17} \\
\hline
\end{tabular}

Table-3: MIC range for vancomycin $(\mu \mathrm{gm} / \mathrm{ml})$ in different clinical isolates

\begin{tabular}{|l|l|l|l|l|l|l|l|}
\hline \multirow{2}{*}{ Clinical isolates } & \multicolumn{7}{|c|}{ MIC Values $(\boldsymbol{\mu g m} / \mathbf{m m})$} \\
\cline { 2 - 9 } & $\leq 0.5$ & 1 & 2 & 4 & 8 & 16 & $\geq 32$ \\
\hline E. faecalis (N=27) & 0 & 0 & 16 & 9 & 3 & 0 & 0 \\
\hline E. faecium (N=26) & 0 & 2 & 16 & 5 & 4 & 0 & 1 \\
\hline E. raffinosus (N= 2) & 0 & 0 & 2 & 0 & 0 & 0 & 0 \\
\hline E. solitarius (N= 3) & 0 & 0 & 3 & 0 & 0 & 0 & 0 \\
\hline E. gallinarum (N= 2) & 0 & 0 & 1 & 0 & 1 & 0 & 0 \\
\hline
\end{tabular}

Table-4: MIC range for vancomycin $(\mu \mathrm{gm} / \mathrm{ml})$ in different faecal isolates

\begin{tabular}{|l|c|c|c|c|c|c|c|}
\hline \multirow{2}{*}{ Stool Isolates } & \multicolumn{6}{|c|}{ MIC Values $(\boldsymbol{\mu g m} / \mathbf{m m})$} \\
\cline { 2 - 8 } & $\leq \mathbf{0 . 5}$ & $\mathbf{1}$ & $\mathbf{2}$ & $\mathbf{4}$ & $\mathbf{8}$ & $\mathbf{1 6}$ & $\geq 32$ \\
\hline E. faecalis (N=28) & 0 & 1 & 9 & 9 & 2 & 6 & 1 \\
\hline E. faecium (N=11) & 0 & 1 & 4 & 3 & 2 & 4 & 2 \\
\hline E. gallinarum (N=22) & 0 & 7 & 7 & 0 & 0 & 4 & 2 \\
\hline E. raffinosus (N=1) & 0 & 0 & 1 & 0 & 0 & 0 & 0 \\
\hline E. dispar (N=1) & 0 & 0 & 0 & 0 & 1 & 0 & 1 \\
\hline
\end{tabular}

